\title{
PERBEDAAN EFEKTIFITAS PENYULUHAN DENGAN MEDIA BOOKLET DAN AUDIOVISUAL TERHADAAP PENGETAHUAN IBU TENTANG GIZI BALITA DI WILAYAH KERJA PUSKESMAS GUNUNG KEMALA PRABUMULIH TAHUN 2019
}

\author{
Inggrid Febri Kurnia Sari' ${ }^{1}$, Yudi Abdul Majid ${ }^{2}$, Trilia ${ }^{3}$ \\ 1,2,3 Program Studi Ilmu Keperawatan, STIKES Muhammadiyah Palembang \\ inggridfebrikurniasari@gmail.com,yudi.majid.33@gmail.com, triliawm13@gmail.com
}

\begin{abstract}
ABSTRAK
Usia balita merupakan fase yang sangat penting dalam menunjang tumbuh kembangnya.Pada usia ini pertumbuhan sangat pesat sehingga memerlukan gizi yang sesuai dengan kebutuhannya agar terhindar dari masalah gizi. Salah satu faktor pengaruh terjadinya masalah gizi adalah kurangnya pengetahuan keluarga, dalam hal ini perawat memiliki peran dalam permasalahan gizi balita salah satunya adalah sebagai pendidik (edukator). Metode pendidikan kesehatan yang sering digunakan adalah ceramah, tetapi beberapa penelitian menunjukan metode ini kurang efektif. Sehingga untuk meningkatkan efektifitas metode ceramah dapat di tambahkan dengan beberapa media seperti booklet dan audiovisual. Tujuan penelitian: diketahuinya efektifitas penyuluhan dengan media booklet dan media audiovisual terhadap pengetahuan ibu tentang gizi balita di wilayah kerja puskesmas gunung kemala prabumulih. Metode Penelitian: Penelitian ini menggunakan desain quasi exsperimen pretes-posttes without control group. Sampel berjumlah 80 responden. Teknik pengambilan sampel purposive sampling, instrument penelitian menggunakan lembar kuesioner. Hasil: Rata-rata pengetahuan responden setelah di lakukan penyuluhan dengan media audiovisual sebesar 13,68 dan median booklet 11,60. Terdapat perbedaan yang signifikan antara rata-rata pengetahuan Responden sebelum dan sesudah di lakukan intervensi. Tidak terdapat perbedaan yang signifikan pengetahuan tentang gizi balita antara kedua kelompok intervensi. Terdapat perbedaan pengetahuan setelah penyuluhan kesehatan yang signifikan antar kedua kelompok intervensi. Kesimpulan: Terdapat perbedaan yang signifikan setelah dilakukan intervensi antara kedua kelompok responden.Berdasarkan hasil disarankan hasil penelitian ini dapat dijadikan tambahan pengetahuan untuk memberikan pendidikan kesehatan responden.
\end{abstract}

Kata Kunci :Pendidikan kesehatan, Pengetahuan, Audiovisual, Booklet, Pengetahuan Tentang Gizi Balita

\begin{abstract}
The age of toddlers is a very important phase in supporting growth and development. At this age, growth is so rapid that it requires nutrients that are in accordance with their needs to avoid nutritional problem. One of the factors influencing the occurrence of nutritional problem is the lack of family knowledge, in this case nurses have a role in underfive nutrition problems that occur one of which is as an educator. The method of health education that is often used is lectures, but several studies show this method is less effective. So that to improve the effectiveness of the lecture method can be added to several media such as booklets and audiovisuals. Purpose: To know the effectiveness of counseling with booklet media and audiovisual media on mothers' knowledge about toddler nutrition in the working area of Puskesmas Gunung Kemala Prabumulih. Method: This study used a pretest-posttest quasiexperimental design without control group. The sample was 80 respondents. Purposive sampling technique was used, research instrument using questionnaire sheets. Result: The
\end{abstract}


average knowledge of respondents after counseling with audiovisual media was 13.68 and median booklets 11.60. There were significant differences between the average knowledge of the respondents before and after intervention. There was no significant difference in knowledge about toddler nutrition between the two intervention groups. There was a difference in knowledge after significant health education between the two intervention groups. Conclusion: There were significant differences after intervention between the two groups of respondents. Based on the results it was suggested that the results of this study could be used as additional knowledge to provide respondents with health education.

\section{Keywords : Health education, Knowledge, Audiovisual, Booklet, Knowledge about Toddler Nutrition}

\section{Pendahuluan}

Anak adalah generasi penerus bangsa yang harus dijaga kualitas pertumbuhan dan perkembangannya agar saat dewasa menjadi lebih produktif dan dapat memajukan bangsa ke arah yang lebih baik (Lisa,2012). Usia lima tahun pertama dalam kehidupan balita merupakan fase yang sangat penting dalam menunjang tumbuh kembangnya, karena pada fase ini balita sangat peka terhadap lingkungan di sekitarnya. Beberapa ahli menyebutkan bahwa usia di bawah lima tahun adalah masa keemasan (golden period) (Kusbiantoro, 2015). Potensi yang dimiliki anak balita sangat besar pada usia ini, oleh karena itu pemenuhan kebutuhan seperti perawatan, asupan nutrisi, kesehatan, daya tahan tubuh, perhatian dan kasih sayang dari orang tua, serta pendidikan sangat penting untuk diperhatikan sehingga balita dapat berkembang secara optimal. Periode balita juga merupakan periode kritis dimana segala penyakit termasuk masalah gizi sering terjadi jika pemenuhan kebutuhanya tidak adekuat. (Setyawati, 2012).

Pada usia balita pertumbuhan seorang anak sangat pesat sehingga memerlukan asupan gizi yang sesuai dengan kebutuhannya (Khomsan,2012). Gangguan gizi pada balita dapat menyebabkan gangguan tumbuh kembang anak, misalnya pendek (Stunting), kurus (Wasting) dan gangguan perkebangan mental (Wirawan, Abdi \& Sulendri, 2014)

Pada tahun 2017, tercatat balita yang mengalami Stunting sekitar 22,2\% atau
150,8 juta anak, wasting $7,5 \%$ atau 50,5 juta anak, dan 5,6\% atau 38,3 juta anak mengalami kelebihan berat badan di seluruh Dunia(Unicef, WHO, TWB, 2018). Global Nutrition Report, menunjukkan Indonesia termasuk dalam 17 negara, di antara 117 negara, yang mempunyai tiga masalah gizi yaitu stunting, wasting dan overweight pada balita (PSG, 2017).

Di Indonesia pada tahun 2017 berdasarkan pemantauan status gizi (PSG) angka balita gizi kurang (underweight) sebanyak 17,8\%, pendek (stunting) $29,6 \%$, kurus (wasting) 9,5\% dan gemuk 4,6\%. Sementara di Sumatera Selatan masalah gizi balita yang terjadi yaitu gizi kurang (underweight) sebayak 12,3\%, pendek (stunting) 22,8\%, kurus (wasting) 7,8\% dan $4,2 \%$ balita mengalami kegemukan, sedangkan di Prabumulih angka gizi kurang (underweight) sebanyak $8,5 \%$, pendek (stunting) 19,3\%, kurus (wasting) 6,7\% dan 3,5\% mengalami kegemukan.

Masalah gizi tidak hanya disebabkan oleh faktor ekonomi atau kemiskinan, masalah gizi juga dipengaruhi oleh faktor pengetahuan, sikap dan juga perilaku yang kurang dalam menciptakan pola hidup yang sehat. Masih tingginya angka anak balita yang menderita gizi kurang di Indonesia menunjukkan bahwa kesadaran masyarakat mengenai gizi masih kurang. Kurangnya pengetahuan dan persepsi mengenai kebutuhan dan nilai pangan pada balita adalah hal yang umum dijumpai. Kurangnya pengetahuan ibu mengenai gizi balita akan berdampak pula pada pemenuhan nutrisi 
pada balita karena pengetahuan merupakan domain yang sangat penting dari terbentuknya perilaku seseorang, termasuk perilaku dalam pemenuhan gizi (Nugrahaeni, 2018). Dalam hal ini perawat juga memiliki peran dalam permasalahan gizi balita yang terjadi salah satunya adalah sebagai edukator. Perawat dapat menyampaikan informasi tentang gizi balita dengan cara penyuluhan Kesehatan tentang gizi balita (Potter \& Perry,2005)

Penyuluhan kesehatan dapat dilakukan dengan berbagai macam metode menyesuaikan sasaran yang akan diberikan pendidikan. Metode penyuluhan kesehatan yang paling sering digunakan untuk berbagi pengetahuan dan fakta kesehatan adalah metode ceramah karena pertimbangan waktu, biaya, tenaga dan sarana. Beberapa peneliti menunjukkan bahwa metode ceramah yang selama ini dilaksanakan kurang efektif (Muthia, 2015). Sehingga untuk meningkatkan efektifitas metode ceramah dapat di tambahkan dengan beberapa media seperti booklet dan audiovisual.

Hasil penelitian oleh Rahayu (2014), menunjukan bahwa terjadi peningkatan pada kelompok eksperimen pada pengetahuan dan tindakan setelah diberikan penyuluhan menggunakan media booklet. Dalam penelitian lain yang dilakukan oleh Mintarsih (2007); Farudin (2011); Yulianti (2013); dan Srimiyati (2014) membuktikan apabila penyuluhan dengan menggunakan booklet mampu meningkatkan pengetahuan dan memperbaiki tindakan responden (Hendriani, 2018).

Hasil penelitian yang dilakukan oleh Muthia (2015), dapat disimpulkan bahwa terjadi peningkatan pada kelompok eksperimen baik pada pengetahuan dan tindakan setelah diberikan penyuluhan menggunakan media audiovisual dan juga pada hasil penelitian yang dilakukan oleh Syarif (2015), Infantri (2011) menunjuk bahwa pendidikan kesehatan yang dalam penelitiannya menggunakan media audiovisual dapat meningkatkan pengetahuan, sikap dan tindakan responden.
Berdasarkan studi pendahuluan yang dilakukan peneliti di dapatkan jumlah ibu yang memiliki balita di wilayah kerja Puskesmas Gunung Kemala Prabumulih berjumlah 403 orang. Di Prabumulih, Puskesmas Gunung Kemala mengalami masalah gizi terbanyak yaitu 37 anak dengan 21 balita mengalami gizi kurang dan 16 balita mengalami pendek (stunting), sedangkan jumlah balita yang mengalami masalah gizi di Puskesmas lain yaitu Puskesmas Prabumulih Barat sebanyak 11 balita, Puskesmas Prabumulih Timur sebanyak 12 balita, Puskesmas Sukajadi sebanyak 20 balita, Puskesmas Karang Raja Delinom sebanyak 26 balita, Puskesmas Tanjung Rambang sebanyak 25 balita dan Puskesmas Tanjung Raman sebanyak 5 balita (Dinkes Prabumulih, 2018). Untuk mengatasi masalah gizi pada balita, Puskesmas Gunung Kemala Prabumulih telah melakukan konsling terhadap ibu yang memiliki balita yang mengalami masalah gizi dan telah melakukan penyuluhan kesehatan menggunakan metode ceramah dengan media yang sering digunakan adalah lembar balik. Puskesmas Gunung Kemala belum pernah menggunakan media booklet dan audiovisual untuk melakukan penyuluhan kesehatan.

Berdasarkan uraian tersebut peneliti tertarik melakukan penelitian untuk membandingkan efektifitas penyuluhan dengan media booklet dan media audiovisual terhadap peningkatan pengetahuan ibu tentang gizi balita di wilayah kerja Puskesmas Gunung Kemala Prabumulih Tahun 2019.

\section{Metode Penelitian \\ Desain Penelitian}

Penelitian ini merupakan jenis penelitian kuantitatif dengan rancangan quasi exsperimen pretes-posttes without control group.

\section{Populasi dan Sampel \\ Populasi}

Populasi dalam penelitian ini adalah semua ibu yang memiliki balita di wilayah kerja 
Puskesmas Gunung Kemala Prabumulih Tahun 2019 yang berjumlah 403 .

\section{Sampel}

Pengambilan sampel pada penelitian ini dengan purposive sampling. Jumlah sampel dalam penelitian ini adalah 80 responden yang di bagi menjadi dua kelompok yaitu kelompok media booklet 40 responden dan kelompok media audiovisual 40 responden, dengan kriteria inkulsi, Ibu yang memiliki balita (1-5 tahun) di wilayah kerja Puskesmas Gunung Kemala Prabumulih, Ibu dapat membaca dan bersedia menjadi responden.

\section{Hasil Dan Pembahasan}

Analisis Univariat

\section{Karakteristik Responden}

Tabel 1

Karakteristik Responden berdasarkan Umur

\begin{tabular}{lllll}
\hline Variabel & Mean & Median & $\begin{array}{l}\text { Standar } \\
\text { Deviasi }\end{array}$ & $\begin{array}{l}\text { Min- } \\
\text { Max }\end{array}$ \\
\hline Umur & 25,40 & 24,50 & 5,789 & $16-$ \\
& & & & 39
\end{tabular}

Dari tabel 5.1 datadiatas menunjukan bahwa rata-rata umur responden dalam penelitian ini adalah 25,40 tahun dengan nilai median 24,50 dan standar deviansi 5,789. Usia termuda yang menjadi responden penelitian ini Berumur 16 tahun sedangkan umur tertua 39 tahun.

Tabel 2

Karakteristik Responden berdasarkan Pendidikan

\begin{tabular}{llll}
\hline Variabel & Kategori & Frekuensi & \% \\
\hline Pendidikan & Dasar(SD,SMP) & 42 & $52,6 \%$ \\
& Menengah(SMA) & 29 & $36,2 \%$ \\
& Lanjutan(D3-S3) & 9 & $11,2 \%$ \\
\hline Jumlah & $\leq 2$ & 64 & $80 \%$ \\
Anak & $>2$ & 16 & $20 \%$ \\
\hline Pekerjaan & Tidak Bekerja & 23 & $28,8 \%$ \\
& Bekerja & 57 & $71,2 \%$ \\
& & &
\end{tabular}

Dari tabel diatas menunjukan bahwa karakteristik responden berdasarkan pendidikan yaitu pendidikan dasar (SD, SMP) berjumlah 42 orang $(52,6 \%)$, Menengah (SMA) berjumah 29 orang $(36,2$ \%) dan Lanjutan

(D3) berjumlah 9 orang (12,2\%). karakteristik responden berdasarkan jumlah anak yaitu ibu yang memiliki $\leq 2$ anak berjumlah 64 orang (80 \%), ibu yang memiliki > 2 anak berjumlah 16 orang (20 $\%)$. Karakteristik responden berdasarkan pekerjaannya yaitu ibu tidak bekerja berjumlah 23 orang $(28,8 \%)$ dan ibu bekerja sebanyak 57 orang $(71,2 \%)$

\section{Skor Pengetahuan tentang Gizi Balita}

Tabel 3

Skor Pengetahuan Ibu Balita tentang Gizi Balita

Sebelum dan Sesudah dilakukan Pendidikan Kesehatan dengan Media Audiovisual

\begin{tabular}{lclll}
\hline Variabel & Mean & Median & $\begin{array}{l}\text { Standar } \\
\text { Deviasi }\end{array}$ & $\begin{array}{l}\text { Min- } \\
\text { Max }\end{array}$ \\
\hline $\begin{array}{l}\text { Pengetahuan } \\
\text { sebelum } \\
\text { intervensi }\end{array}$ & 10,00 & 9,50 & 4,315 & $3-19$ \\
\hline $\begin{array}{l}\text { Pengetahuan } \\
\text { sesudah } \\
\text { intervensi }\end{array}$ & 13,68 & 13,50 & 4,184 & $7-21$ \\
\hline
\end{tabular}

Tabel diatas menunjukan rata-rata pengetahuan ibu balita sebelum dilakukan pendidikan kesehatan dengan media audiovisual adalah 10,00 dengan median 9,50 dan standar deviasi 4,315. Nilai pengetahuan ibu terendah sebelum di lakukan pendidikan kesehatan yaitu 3 dan tertinggi yaitu 19. Hasil rata-rata pengetahuan ibu setelahah dilakukan pendidikan kesehatan dengan media audiovisual 13,68 dengan median 13,50 dan standar deviasi 4,184 . Nilai pengetahuan ibu terendah setelah dilakukan pendidikan kesehatan yaitu 7 dan tertinggi yaitu 21 . 
Tabel 4

Analisa Data Skor Pengetahuan Ibu Balita tentang Gizi Balita Sebelum dan Sesudah dilakukan Pendidikan Kesehatan dengan Media Booklet

\begin{tabular}{lcccc}
\hline Variabel & Mean & Median & $\begin{array}{l}\text { Standar } \\
\text { Deviasi }\end{array}$ & $\begin{array}{l}\text { Min- } \\
\text { Max }\end{array}$ \\
\hline $\begin{array}{l}\text { Pengetahuan } \\
\text { sebelum } \\
\text { intervensi }\end{array}$ & 10,02 & 10,50 & 4,129 & $2-19$ \\
\hline $\begin{array}{l}\text { Pengetahuan } \\
\text { sesudah } \\
\text { intervensi }\end{array}$ & 11,60 & 12,00 & 4,511 & $4-20$ \\
\hline
\end{tabular}

Hasil tabel 5.3 data diatas menunjukan rata-rata pengetahuan ibu balita sebelum dilakukan pendidikan kesehatan dengan media booklet adalah 10,02 dengan median 10,50 dan standar deviasi 4,129. Nilai pengetahuan ibu terendah sebelum di lakukan pendidikan kesehatan yaitu 2 dan tertinggi yaitu 19. Hasil rata-rata pengetahuan ibu setelahah dilakukan pendidikan kesehatan dengan media booklet 11,60 dengan median 12,00 dan standar deviasi 4,511. Nilai pengetahuan ibu terendah setelah dilakukan pendidikan kesehatan yaitu 4 dan tertinggi yaitu 20.

\section{Analisis Bivariat}

Tabel 5

Perbedaan Pengetahuan Ibu tentang Gizi Balita Sebelum dan Sesudah di Lakukan Penyuluhan

\begin{tabular}{ccccc}
\hline variabel & & Mean & SD & $\begin{array}{c}\boldsymbol{p} \\
\text { Value }\end{array}$ \\
\hline $\begin{array}{c}\text { Pengetahuan } \\
\text { dengan } \\
\text { media } \\
\text { audiovisual }\end{array}$ & $\begin{array}{c}\text { Pre } \\
\text { test }\end{array}$ & 10,0 & 4,315 & \\
\cline { 2 - 4 } & $\begin{array}{c}\text { Post } \\
\text { test }\end{array}$ & 13,68 & 4,184 & \\
\hline $\begin{array}{c}\text { Pengetahuan } \\
\text { dengan } \\
\text { media } \\
\text { booklet }\end{array}$ & $\begin{array}{c}\text { Pre } \\
\text { test }\end{array}$ & 10,02 & 4,129 & \\
\cline { 2 - 4 } & $\begin{array}{c}\text { Post } \\
\text { test }\end{array}$ & 11,6 & 4,511 & \\
\hline
\end{tabular}

Hasil analisis menggunakan uji paired sample t-tes untuk mengetahui perbedaan pengetahuan setelah diberikan pendidikan kesehatan dengan menggunakan media audiovisual dan media booklet, didapatkan hasil $p$ value $=0,000$, artinya terdapat perbedaan yang signifikan antara sebelum dan setelah intervensi. Setelah dilakukan pendidikan kesehatan dengan menggunakan media audiovisual nilai ratarata pengetahuan ibu dari 10,00 menjadi 13,68 sedangkan dengan media booklet ratarata pengetahuan ibu dari 10,02 menjadi 11,60 .

Tabel 6

Perbedaan Pengetahuan Ibu tentang GiziBalita Sebelum dan Sesudah di Lakukan Penyuluhan antara kelompok Audiovisual dan Booklet

\begin{tabular}{lcccc}
\hline Variabel & Media & Mean & $\begin{array}{c}\text { Standar } \\
\text { Deviasi }\end{array}$ & $\begin{array}{c}\boldsymbol{p} \\
\text { Value }\end{array}$ \\
\hline \multirow{2}{*}{ Pre test } & Audiovisual & 10,00 & 4,315 & 0,979 \\
\cline { 2 - 4 } & booklet & 10,02 & 4,129 & \\
\hline \multirow{2}{*}{ Post test } & Audiovisual & 13,68 & 4,182 & \multirow{2}{*}{0,036} \\
\cline { 2 - 4 } & booklet & 11,60 & 4,511 & \\
\hline
\end{tabular}

Hasil analisis menggunakan independent sampel t-test untuk membandingkan uji komparasi antara dua sampel bebas (independent), didapatkan pengetahuan responden sebelum dilakukan penyuluhan dengan media audiovisual dan booklet dengan nilai $p$ value $=0,979$, artinya tidak terdapat perbedaan yang signifikan antara pengetahuan responden sebelum dilakukan penyuluhan dengan media audiovisual dan booklet. Sedangkan pada pengetahuan responden setelah dilakukan penyuluhan dengan media audiovisual dan booklat dengan nilai $p$ value $=0,036$, artinya terdapat perbedaan yang signifikan antara pengetahuan responden setelah dilakukan penyuluhan dengan media audiovisual dan booklet.

\section{Pembahasan}

Berdasarkan analisa univariat pada penelitian telah dilakukan terhadap 80 responden dan di bagi menjadi 2 kelompok intervensi yaitu penyuluhan dengan media audiovisual dan booklet sehingga masing- 
masing kelompok berjumlah 40 responden, sehingga didapatkan rata-rata pengetahuan ibu tentang gizi balita sebelum dilakukan penyuluhan dengan media audiovisual sebesar 10,00, dengan skor median 9,50 dan standar deviasi 4,315 . Skor pengetahuan ibu tentang gizi balita sebelum dilakukan pendidikan kesehatan dengan media audiovisual terendah yaitu 3 dan tertinggi yaitu 19. Sedangkan rata-rata pengetahuan ibu tentang gizi balita setelah dilakukan penyuluhan dengan media audiovisual sebesar 13,68, dengan skor median 13,50 dan standar deviasi 4,184. Skor pengetahuan ibu tentang gizi balita setelah dilakukan pendidikan kesehatan dengan media audiovisual terendah terendah yaitu 7 dan tertinggi yaitu 21 .

Di kelompok intervensi penyuluhan dengan media booklet rata-rata pengetahuan ibu tentang gizi balita sebelum dilakukan penyuluhan dengan media booklet sebesar 10,02, dengan skor median 10,50 dan standar deviasi 4,129. Skor pengetahuan ibu tentang gizi balita sebelum dilakukan pendidikan kesehatan dengan media booklet terendah yaitu 2 dan tertinggi yaitu 19 . Sedangkan rata-rata pengetahuan ibu tentang gizi balita setelah dilakukan penyuluhan dengan media booklet sebesar 11,60, dengan skor median 12,00 dan standar deviasi 4,511. Skor pengetahuan ibu tentang gizi balita setelah dilakukan pendidikan kesehatan dengan media booklet terendah terendah yaitu 4 dan tertinggi yaitu 20.

Hasil penelitian ini sejalan dengan teori Bloom yaitu individu atau kelompok setelah diberikan pendidikan kesehatan dapat meningkatkan 3 domain yaitu kognitif, afektif dan psikomotor. Individu atau kelompok setelah diberikan pendidikan kesehatan akan melalui proses mengingat materi yang telah dipelajari, selanjutnya individu akan memahami comprehension) yaitu kemampuan untuk menjelaskan dan mengintepretasikan secara benar, kemudian melakukan aplikasi dari materi yang telah dipelajari, dan menganalisis dari hasil tindakan yang telah diaplikasikan (Notoadmojo, 2014).

Dari hasil diatas terlihat terjadi peningkatan skor pengetahuan setelah dilakukan pendidikan kesehatan. Hasil penelitian ini sesuai dengan penelitian yang dilakukan Kumboyono (2011) perbedaan efek penyuluhan dengan menggunakan media cetak dan media audiovisual terhadap peningkatan pengetahuan. Penelitian yang dilakuakan oleh Purniawan (2016) pendidikan kesehatan dengan menggunakan media yang bersamaan yaitu media cetak poster dan video dapat meningkatkan pengetahuan ibu tentang $\mathrm{TB}$ paru dan pencegahannya.

Usia merupakan salah satu faktor yang dapat menggambarkan kematangan seseorang (Khotimah \& Kuswandi, 2014). Hasil penelitian ini diperoleh usia rata-rata ibu dalam penelitian ini adalah 25 tahun yang merupakan usia produktif. Menurut No 13 tahun 2003 yang menyatakan bahwa usia produktif seseorang yaitu antara 15 tahun hingga 64 tahun.

Semakin tua umur seseorang maka proses-proses perkembangan mentalnya bertambah baik, akan tetapi pada umur tertentu, bertambahnya proses perkembangan mental ini tidak secepat seperti ketika berumur belasan tahun. Bertambahnya umur seseorang dapat berpengaruh pada pertambahan pengetahuan yang diperolehnya, akan tetapi pada umur-umur tertentu atau menjelang usia lanjut kemampuan penerimaan atau mengingat suatu pengetahuan akan berkurang (Ariani,2014). Pada penelitian ini umur ibu yang menjadi responden merupakan usia yang produktif yaitu 16 tahun sampai 39 tahun, sehingga pada usia ini responden dapat menerima penjelasan dengan baik.

Berdasarkan hasil penelitian dan teori yang ada maka peneliti berpendapat bahwa pengetahuan ibu tentang gizi balita akan meningkat jika di berikan penyuluhan atau pendidikan kesehatan dengan media audiovisual maupun booklet. Ini terlihat dari 
rata-rata skor pengetahuan responden dari kedua kelompok tersebut meningkat.

Menurut Ihsan, Hiswani, dan Jemadi (2013) pendidikan ibu merupakan faktor yang tidak langsung yang dapat mempengaruhi status gizi balita. Pengetahuan dan pendidikan ibu menjadi salah satu faktor yang dapat menentukan status gizi keluarga, karena pendidikan tersebut dapat membantu sampainya informasi mengenai kesehatan gizi (Rohaedi, Julia, \& Gunawan, 2014).Semakin tinggi tingkat pendidikan seseorang maka akan semakin mudah menyerap informasi maupun menerapkan pengetahuannya khususnya dalam hal kesehatan dan gizi. Dengan demikian diharapkan semakin tinggi pendidikan seseorang akan semakin baik pula pengetahuannya. Akan tetapi beberapa penelitian menyebutkan bahwa balita dengan status gizi kurang berasal dari ibu yang berpendidikan tinggi. Hal ini dapat dikarenakan ibu tidak menerapkan pengetahuan yang ia miliki (Putri, Sulastri \& Lestari, 2015).

Tingkat pendidikan seseorang dapat menentukan cara berfikir dari seseorang tersebut. Hal tersebut dikarenakan seseorang yang berpendidikan tinggi biasanya mempunyai wawasan yang lebih luas dibandingkan dengan seseorang dengan pendidikan rendah. Meskipun demikian, seseorang dengan pendidikan rendah belum tentu memiliki wawasan yang sempit karena apabila seseorang tersebut aktif dalam mencari dan mendapatkan informasi yang diinginkan maka wawasan dari seseorang yang berpendidikan rendah tersebut akan sama baiknya dengan seseorang yang berpendidikan tinggi (Arbella, Widyastuti \& Rahayu, 2013). Dalam penelitian ini pendidikan responden yaitu pendidikan dasar (SD, SMP) berjumlah 42 orang (52,6\%), Menengah (SMA) berjumah 29 orang (36,2\%) dan Lanjutan (D3) berjumlah 9 orang $(12,2 \%)$. Dari hasil penelitian skor pengetahuan ibu sebelum dilakukan penyuluhan rendah dikarenakan kebanyakan pendidikan responden merupakan ibu yang memiliki pendidikan dasar atau rendah $(52,6 \%)$.

Status pekerjaan ibu merupakan salah satu faktor yang dapat berpengaruh terhadap pertumbuhan maupun perkembangan anak usia balita. Sebagian besar ibu dalam penelitian ini adalah bekerja yaitu sebanyak57 ibu $(71,2 \%)$ dan sisanya adalah ibu rumah tangga atau tidak bekerja $(28,8 \%)$. Status pekerjaan ini menjadikan ibu memiliki tambahan peran dan tanggung jawab dalam hal mencari nafkah. Ibu yang bekerja akibatnya memiliki peran ganda sehingga sering dihadapkan dengan konflik antara pekerjaan dan peran ibu dalam keluarga. Tuntutan dalam pekerjaan yang menyita waktu menjadikan waktu yang ibu miliki dalam keluarga semakin sedikit sehingga waktu untuk menccari informasi tentang gizi balita dan informasi lain pun berkurang (Putri \& Kusbaryanto, 2012). Dikarenakan waktu yang kurang untuk menerima informasi dalam penelitian ini skor pengetahuan yang di dapat pada penelitian ini rendah.

Berdasarkan hasil analisa bivariat pengethuan sebelum dan sesudah intervensi antra dua kelompok, didapatkan rata-rata pengetahuan ibu tentang gzi balita sebelum dilakukan pendidikan kesehatan yaitu 10,0 sedangkan setelah dilakukan penyuluhan kesehatan rata-rata pengetahuan ibu tentang gizi balita yaitu 13,68. Berdasarkan hasil uji paired t-test didapatkan $\mathrm{p}$ value $=0,000$ dengan nilai $\alpha<0,05$ berarti ada pengaruh sebelum dan sesudah dilakukan pendidikan kesehatan menggunakan media audiovisual terhadap pengetahuan ibu tentang gizi balita dengan perbedaan rata-rata skor 3,68. Hasil penelitian ini sejalan dengan teori bahwa media audiovisual merupakan alat bantu dalam menerima pesan sehingga dapat memperoleh ilmu dan pengalaman yang bermanfaat untuk mencapai tujuan.Media audiovisual sebuah media yang mengandalkan pendengaran dan penglihatan, serta media untuk meningkatkan ketajaman otak sehingga seseorang menjadi mudah untuk mengingat (Cahyo, 2011). 
Media audio visual adalah media pengajaran dan media pendidikan yang mengaktifkan mata dan telinga peserta didik dalam waktu proses belajar mengajar berlangsung. media audio visual yaitu jenis media yang selain mengandung unsur suara juga mengandung unsur gambar yang dapat dilihat, seperti rekaman video, berbagai ukuran film, slide suara, dan lain sebagainya. Kemampuan media ini dianggap lebih baik dan lebih menarik (Sajaya, 2011).

Manfaat dari media audiovisual membuat informasi lebih menarik, memungkinkan hasil belajar lebih baik, memberikan pengalaman yang nyata, dan media ini dapat digunakan berulangkali, multimedia dapat mengintegrasikan teks, grafik, animasi, audio dan video sehingga lebih menarik dan dinamik (Julianta, 2009).

Penelitian ini sejalan dengan penelitian yang dilakukan Jusmini (2012) pendidikan kesehatan dengan media audiovisual efektif meningkatkan pengetahuan tentang kemampuan merawat bayi baru lahir.

Berdasarkan hasil penelitian dan teori yang ada maka peneliti berpendapat bahwa pengetahuan ibu tentang gizi balita mengalami perubahan signifikan setelah dilakukan pendidikan kesehatan. Menurut asumsi peneliti, peningkatan pengetahuan ibu salah satunya didukung oleh penggunaan media audiovisual. Isi media audiovisual sesuai dengan materi penyuluhan yang disampaikan dengan gambar dan warna serta menyajikan seluruh poin-poin materi pada media audiovisual di dalam kuesioner.

Berdasarkan hasil analisa bivariat didapatkan rata-rata pengetahuan ibu tentang gzi balita sebelum dilakukan pendidikan kesehatan yaitu 10,02 sedangkan setelah dilakukan penyuluhan kesehatan rata-rata pengetahuan ibu tentang gizi balita yaitu 11,60. Berdasarkan hasil uji paired t-test didapatkan $\mathrm{p}$ value $=0,000$ dengan nilai $\alpha<0,05$ berarti ada pengaruh sebelum dan sesudah dilakukan pendidikan kesehatan menggunakan media booklet terhadap pengetahuan ibu tentang gizi balita dengan perbedaan rata-rata skor 1,58.

Hasil penelitian ini sesuai dengan teori bahwa booklet merupakan salah satu alat peraga atau media dalam menyampaikan pesan-pesan kesehatan dalam bentuk buku, booklet berisi tulisan maupun gambar, media booklet dapat menstimulasi indra penglihatan, sehingga lebih mudah dalam menyampaikan informasi, dapat membatasi ruang dan waktu, lebih realistis dibandingkan dengan hanya menggunakan media verbal, penyuluhan dapat dilakukan sewaktu-waktu, dapat dibawa kemana mana, dan dapat meningkatkan gairah belajar karena memuat gambar dan tulisan (Uha Suliha, 2013).

Penelitian ini sejalan dengan Penelitian yang dilakukan oleh Rahayu (2014) yang menggunakan media booklet menunjukkan pengetahuan pretes sebelum eksperimen sebesar $32,92 \%$ setelah mendapatkan pendidikan kesehatan dengan media booklet meningkat sebesar $81,46 \%$. Penelitian lain yang dilakukan oleh Dewi (2012), Mintarsih (2007), Fahrudin (2011), dan Setiyoso (2011) membuktikan pendidikan kesehatan dengan media booklet mampu meningkatkan pengetahuan dan memperbaiki tindakan responden.

Media booklet pada panelitian ini terbukti efektif dalam meningkatakan pengetahuan ibu tentang gizi balita hal ini sesuai dengan Media booklet walaupun termasuk dalam media cetak, merupakan media yang menarik, terdiri dari sedikitnya 5 halaman dan tidak lebih dari 48 halaman, bahasa ringkas dan mudah dipahami, terdapat gambar, bahasa yang menarik, dan dicetak di kertas yang bagus sehingga menarik untuk dibaca (Hermaningsih \& Nargis, 2013). informasi yang ditulis berbentuk buku atau booklet merupakan informasi tertulis yang penting untuk meningkatkan pengetahuan ibu tentang gizi balita, Desain booklet yang menarik akan berpengaruh terhadap motivasi untuk membaca, sehingga akan meningkatkan pengetahun ibu tentang gizi balita. 
Berdasarkan hasil independent sample t-tast pada pengeahuan ibu tentang gizi balita setelah dilakukan intervensi dengan media audiovisul didapatkan $p$ value $=0,036$ dengan nilai $\alpha<0,05$ berarti ada perbedaan yang signifikan antara pengetahuan ibu setelah dilakukan penyuluhan dengan media audiovisual dan booklet. Pada penelitian ini rata-rata skor pengetahuan responden setelah dilakukan penyuluhan dengan media audiovisual sebesar 13,68 sedangkan rata-rata skor pengetehuan setelah dilakukan penyuluhan dengan media booklet sebesar 11,60. Sehingga rata-rata skor pengetahuan responden yang mendapat penyuluhan dengan media audiovisual lebih besar 2,08 . Karena hasil rata-rata nilai pengetahuan penyuluhan dengan media audiovisual lebih besar di banding booklet peneliti berpendapat bahwa media audiovisual lebih efektif dari pada media booklet. Sejalan dengan teori Edgar Dale dalam Notoatmodjo (2007), tentang penyuluhan dengan alat peraga dalam bentuk kerucut, Dari kerucut tersebut dapat dilihat bahwa lapisan yang paling dasar adalah benda asli dan yang paling atas adalah kata-kata.

Berdasarkan teori diatas peneliti berpendapat bahwa penyuluhan dengan media audiovisual lebih efektif dibandingkan booklet, karena media audiovisual menggunakan panca indra lebih banyak yaitu penglihatan dan pendengaran sedangkan booklet hanya menggunakan indra penglihatan. Selain itu berdasarkan teori kerucut edgar dale dalam Notoatmodjo (2007) media rekaman/ audiovisual lebih tinggi intensitasnya dibandingkan tulusan atau media cetak (booklet)

\section{Keimpulan}

Simpulan dari hasil penelitian ini adalah ada Ada perbedaan yang signifikan antara skor pengetahuan ibu tentang gizi balita setelah dilakukan penyuluhan antara kelompok media booklet dan kelompok media audiovisual dengan $p$ value 0,036 ( $p$ value $<0,05$ )

\section{Saran}

\section{Bagi Institusi Pendidikan}

Diharapkan pada tahun yang akan datang institusi pendidikan dapat melengkapi referensi buku-buku mengenai konsep khususnya mengenai keperawatan komunitas guna menunjang penelitian mahasiswa dalam menyelesaikan penelitian.

\section{Bagi Institusi Puskesmas Gunung Kemala}

Diharapkan hasil penelitian ini dapat dijadikan tambahan pengetahuan bagi puskesmas gunung kemala. Selain itu diharapkan pihak puskesmas dapat menerapkan penyuluhan menggunakan kedua media tersebut untuk meningkatkan pengetahuan masyarat.

\section{Untuk Penelitian Selanjutnya}

Diharapkan hasil penelitian ini dapat dijadikan rekomendasi bagi peneliti selanjutnya untuk melakukan penelitian, khususnya untuk keperawatan komunitas , baik melalui metode penelitian kualitatif ataupun kuantitatif. Topik yang Disarankan:

1.) Membandingkan penyuluhan media booklet dan leaflet

2.) Menambahkan variabel dependen sikap dan prilaku

\section{Daftar Pustaka}

Ariani, A., P. (2014). Aplikasi Metodologi Penelitian Kebidanan dan Reproduksi. Yogyakarta : Nuda Medika

A Potter \& Perry,A. G,.(2005). Buku ajar Fundamental Keperawatan : Konsep, Proses, dan Praktik, edisi 4, Volume 2. Jakarta :EGC

Azria, C.R \& Husnah (2016). Pengaruh Penyuluhan Gizi terhadap Pengetahuan dan Perilaku Ibu Tentang Gizi Seimbang Balita Kota Bandar Aceh 
Devi, Nirmala. (2010). Nutrition And Food Gizi Untuk Keluarga. Jakarta : Kompas.

Departemen Kesehatan RI. (2006). Profil Kesehatan 2007 : Kementrian Kesehatan RI

Departemen Kesehatan RI. (2007). Profil Kesehatan 2007 : Kementrian Kesehatan RI

Departemen Kesehatan RI. (2014). Pedoman Gizi Seimbang. Jakarta : Kementrian Kesehatan RI

Dinas Kesehatan Prabumulih (2018). Rekapitulasi Laporan Gizi Puskesma Prabumuluh

Hardiansyah .(2012). Faktor Determinan Keragaman Konsumsi Pangan. Jakarta : Jurnal Gizi dan pangan

Hartono, Andry. (2006). Terapi Gizi Dan Diet Rumah Sakit. Jakarta : EGC.

Hendriani, D., Qona'ah, A \& Firdaus, R. (2018). Pengaruh Media Pendidikan Kesehatan Terhadap Pengetahuan Remaja tentang Premenstrual Syndrome pada Remaja SMP Islam Ar-Riyadh Botang. Mahakam Midwifery Journal

Hidayat. (2011). Pengantar Ilmu Keperawatan Anak 1. Jakarta : Salemba Medik

Kementrian Kesehatan RI. (2014). Pedoman Gizi Seimbang. Jakarta : Kementrian Kesehatan RI

Muthia, Fitriangga, Yanti. (2015) Perbedaan Efektifitas Penyuluhan Kesehatan Metode Ceramah dan Media Audiovisual (Film) terhadap Pengetahuan Santri Madrasah Aliyah Pesantren Khulfaur Rasidin tentang TB Paru Tahun 2015
Natoatmodjo .(2012). Metode Penelitian Kesehatan . Jakarta : Rineka Cipta

Nursalam. (2013). Manajemen Keperawatan. Aplikasi dalam Praktik Keperawatan Profesional, edisi 3, Jakarta : Salemba Medika

Riset Kesehatan Dasar.(2013). Riset Kesehatan Dasar. Jakarta: Riskesdas.

Riyadi, S \& Sukarmin .(2009). Asuhan Keperawatan Pada Anak, Edisi 1, Yogyakarta : Graha Ilmu

Rusmil, Kusnadi.(2008). Pertumbuhan Dan Perkembangan Anak

Saputri, E.L \& Syamuqy, A. (2014) Hubungan Riwayat Pengetahuan Asi Eksklusif dengan Kejadian Obesitas Anak. Jurnal

Setiadi. (2013). Konsep dan Praktek Penulisan Riset Keperawatan (Ed.2) Yokyakarta : dalam Bidang Kesehatan. Yogyakarta : Nuha Medika

Setyawati, Vilda Ana Veria. (2012). Peran status gizi terhadap kecerdasan kognitif pada masa golden age period. Jurnal Visikes, 11(2).

Soekirman. (2012). Ilmu Gizi dan Aplikasinya untuk Keluarga dan Masyarakat, Direktorat Jendral Pendidikan Tinggi Departemen Pendidikan Nasional. Jakarta

Syamsussabri, Muhammad. (2013). Konsep Dasar Pertumbuhan dan Perkembangan Peserta Didik, Jurnal Perkembangan Peserta Didik. Volume 1 Nomor 1.

Undang-Undang No 35 tahun 2014 tentang Perlindungan Anak 
United Nations Children's Fund (UNICEF), WHO, \& International Bank for Reconstruction and Development/The World Bank. (2018). Levels and trends in child malnutrition: key findings of the 2018 Edition of the Joint Child Malnutrition Estimates. Geneva: World Health Organization.

Uripi, V. (2004). Menu Sehat Balita. Jakarta : Puspa Swara

Widjaja. (2008). Gizi Tepat Untuk Perkembangan Otak Dan Kesehatan Balita. : Kawan Pustaka.

Wirawan, S., Abdi, L.K \& Sulendri N.K.S . (2014). Penyuluhan dengan Media Audiovisual dan Konvensional Terhadap Pengetahuan Gizi Balita. Universitas Negeri Semarang.

Wong \& Donna ,I.(2008). Buku Ajar Keperawatan Pediatrik. Jakarta : EGC

Zulaekah, S .(2012). Pendidikan Gizi dengan Media Booklet terhadap Pengetahuan Gizi. Universitas Negeri Semarang. 